\title{
Playing development roles: the political ecology of performance in agricultural development
}

\author{
Andrew Flachs ${ }^{1}$ \\ Paul Richards \\ Purdue University, USA \\ Njala University, Sierra Leone
}

\begin{abstract}
Performance is a useful lens through which to analyze agrarian life, as performance illuminates the ways that farmers manage the complex socioecological demands of farm work while participating in social life and in the larger political economy. The dialectic of planning and improvisation in the farm field has produced scholarship at multiple scales of political ecology, including the global ramifications of new technologies or policies, as well as the hyper-local engagements between farmers and fields in the context of modernity and development. Political ecologists are also beginning to understand how affects, such as aspirations and frustrations, influence agriculture by structuring how farmers and other stakeholders make decisions about farms, households, capital, and environments. To understand farm work as a performance is to situate it within particular stages, roles, scripts, and audiences at different scales. The articles in this Special Section ask how farmers have improvised, planned, and performed in response to agroecological challenges, bridging scholarship in political ecology, development studies, and the study of agrarian landscapes through new empirical case studies and theoretical contributions. Agriculture both signals social values and fosters improvisations within farming communities' collective vulnerability to weather and the political economy. We argue that the lens of performance situates the political ecology of agriculture within the constraints of the political economy, the aspirations and frustrations of daily life, and the dialectic between improvised responses to change and planning in the field.
\end{abstract}

Keywords: Performance, agriculture, planning, improvisation, agrarian studies

\section{Résumé}

La performance est une lentille utile à travers laquelle analyser la vie agraire, car la performance éclaire la manière dont les agriculteurs gèrent les exigences socio-écologiques complexes du travail agricole, tout en participant à la vie sociale et à l'économie politique au sens large. La dialectique de la planification et de l'improvisation dans le domaine agricole a produit des connaissances à de multiples échelles de l'écologie politique, y compris les ramifications mondiales des nouvelles technologies ou politiques, ainsi que les engagements hyper-locaux entre les agriculteurs et leurs champs. Les écologistes politiques commencent également à comprendre comment les influences, telles que les aspirations et les frustrations, influencent l'agriculture en structurant la façon dont les agriculteurs et les autres parties prenantes prennent des décisions concernant les fermes, les ménages, le capital et l'environnement. Comprendre le travail agricole comme une performance signifie le situer dans des étapes, rôles, scripts et publics particuliers à différentes échelles. Les

\footnotetext{
${ }^{1}$ Dr. Andrew Flachs, Assistant Professor, Department of Anthropology, Purdue University, West Lafayette, Indiana, USA. Email: aflachs "at" gmail.com. Dr. Paul Richards, Adjunct Professor, Njala University, Sierra Leone; Emeritus Professor of Technology and Agrarian Development, Wageningen University, Netherlands; and Honorary Professor of Anthropology, University College London, UK. Email: paul.richards1945 "at" gmail.com. The articles in this collection were prepared as part of a workshop funded by the Volkswagen Foundation at the Karl Jaspers Centre for Transcultural Studies at Heidelberg University. We are grateful to all workshop participants for their contributions to this collection, to two anonymous reviewers, and to Simon Batterbury for working with us to publish this Special Section. This is the introduction to Andrew Flachs (ed.). 2018. "Performing development roles: theorizing agriculture as performance", Special Section of the Journal of Political Ecology 25: 638-764.
} 
articles de cette section spéciale demandent comment les agriculteurs ont improvisé, planifié et exécuté en réponse aux défis agroécologiques. Ils établissent un lien entre l'érudition en écologie politique, les études sur le développement et l'étude des paysages agraires par le biais de nouvelles études de cas empiriques et de contributions théoriques. L'agriculture signale des valeurs sociales et favorise les improvisations au sein de la vulnérabilité collective des communautés agricoles face aux conditions météorologiques et à l'économie politique. Nous soutenons que la lentille de la performance situe l'écologie politique de l'agriculture dans les contraintes de l'économie politique, les aspirations et les frustrations de la vie quotidienne et la dialectique entre les réponses improvisées au changement et la planification sur le terrain.

Mots-clés: Performance, agriculture, planification, improvisation, études agraires

\section{Resumen}

El performance es un lente útil a través del cual se puede analizar la vida agraria, al ilustrar las formas en que los campesinos resuelven las complejas demandas socioecológicas del trabajo en el campo, mientras participan en la vida social y en una más amplia economía política. La dialéctica de la planeación e improvisación en el campo del cultivo, ha producido estudios en ecología política a varias escalas, incluyendo las ramificaciones de nuevas tecnologías o políticas, así como en la participaciones hiperlocales entre campesinos y los campos en el contexto de la modernidad y el desarrollo. Interesados en ecología política están comenzando a entender cómo sentimientos, tales como aspiraciones y frustraciones, influyen en la agricultura al estructurar cómo los agricultores y otros actores, toman decisiones sobre granjas, hogares, capital y entornos. Entender el trabajo agrícola como performance, requiere situarlo dentro de etapas, labores, textos y audiencias particulares a diferentes escalas. Los artículos en esta sección especial cuestionan cómo los agricultores han improvisado, planeado y actuado en respuesta a los retos agroecológicos, vinculando estudios en ecología política, estudios de desarrollo, y el estudio de los paisajes agrarios a través de nuevos casos de estudio empírico y contribuciones teóricas. La agricultura indica valores sociales y fomenta improvisaciones en el marco de la vulnerabilidad colectiva al clima y la economía política en comunidades agrícolas. Aquí discutimos que el lente del performance sitúa a la ecología política de la agricultura dentro de los límites de la economía política, las aspiraciones y frustraciones de la vida cotidiana, y la dialéctica entre las respuestas que se improvisan ante el cambio y la planeación en el campo.

Palabras clave: Performance, agricultura, planeación, improvisación, estudios agrarios

\section{Performance and agriculture}

Performance is a powerful and versatile analytic lens in social theory, describing ritual roles and dramas that reflect power in society (Turner 1970, 1980), the actions that signify and enact social identities that are always and already there (Butler 1990), the strategic presentations of self that help people navigate complicated social spaces (Goffman 1956, 1959), the iterative adaptations and course corrections of skilled practitioners responding to variability in daily life (Richards 1993; Scott 1998), the interpretation of practices or events by participants and various audiences (Schieffelin 1998), or the use of scripts to justify decision-making and roleplaying in a development context (Vanclay and Enticott 2011). Scholarship in agrarian studies and development studies has used the language of performance to understand how farmers manage the complex socioecological demands of farm work while navigating postcolonial identity (Gupta 1998; Pandian 2009), state, colonial, corporate, or non-governmental interventions in indigenous technical knowledge (Richards 1985; Stone 2016), and global environmental change that threatens to impact marginal agricultural communities hardest (Crane et al. 2011). This Special Section asks how farmers have improvised, planned, and performed in response to these challenges, bridging scholarship in political ecology, development studies, and the study of agrarian landscapes through new empirical case studies and theoretical contributions.

In two influential works, Paul Richards $(1989,1993)$ describes small-scale agriculture as a type of performance that requires improvisation, repertoire, experiential knowledge, stage presence, and an active audience. Just as musicians learn to 'play through' mistakes or improvise to match hall acoustics and audience moods when they play, farmers develop adaptive strategies to confront agronomic issues framed within a larger political economy. Richards argues that these completed performances, the farm fields, reflect not a preconceived design logic so much as an emergent improvisation to factors including weather, soil conditions, 
input costs, labor, and available seeds. In the daily performances of agriculture, farmers call upon an experiential repertoire to manage these environmental, social, and economic farm variables. To understand agriculture in practice, social scientists must understand how this improvisatory skillset is put to use in the hyper-local context of individual farm fields (Richards 1993: 67).

Reading Richards' metaphor at face value, performance is not a heuristic to describe differing presentations of self in the sense developed by sociologist Erving Goffman (1959), but a literal farm level response to droughts, pests, shortages, or other opportunities and constraints on household resources. Agricultural performances emerge spontaneously as improvisations when farmers struggle to keep their land, plants, households, projects, and livelihoods viable. Richards extends the language of performance and improvisation to describe agricultural decision-making, spurring research in indigenous knowledge (Stone 2007), sustainable development (Murdoch and Clark 1994), and adaptation in dynamic environments (Orlove et al. 2010).

The question of improvisation in situ challenges the analytic value of agricultural field trials used in many studies of agricultural development economics, and provides a data-driven critique of development programs that cast small farmers as incapable of managing farm resources or innovating in markets or households ( Brookfield 2001; Netting 1993; Richards 1985). Rather, these and other scholars described smallscale agriculture ethnographically, as an iterative practice based in a series of diverse, adaptive strategies to manage labor and resources over the long term within a limited space (Alcorn and Toledo 1998; Leslie and McCabe 2013; Netting 1993; Sumberg and Okali 1997). While providing a useful critique of agricultural development, the focus on improvisation does little to illuminate the stage. Scholarship informed by political ecology must also consider the wider context in which agriculture occurs (Batterbury 2017) - land tenure, capital, national policies, climate change, gender roles, and the other innumerable constraints of agricultural work. Political ecology and performance must be considered, then, in tandem.

\section{The political ecology of agricultural performances}

While performance has been a persistent theme in the scholarship of agrarian development over the last 25 years, performance has not always been explicitly connected to the larger political economy or theories of postcolonialism, which ask how small-scale farmers engage with development programs at local, state, and international scales (Agrawal 2005; Escobar 1995; Gupta 1998; Vasavi 1999). Empirically-grounded work has shown that farmers are not passive recipients of aid, but actively shape that development to their own needs (Vanclay 2004; Vanclay and Lawrence 1994). This shaping involves improvisations as well as planned labor and resource arrangements (Batterbury 1996) that must work within the disputes, risks, opportunities, and needs of the local community (Agrawal and Sivaramakrishnan 2000; Flachs 2016). This relationship is dynamic, as development intermediaries from states, NGOs, or the private sector intervene in farmer performances by providing new incentives, sources of expertise, and audience reactions (Kumar 2015). Small scale farming is often a moral as well as an agricultural process (Pandian 2009), and so the performance of development and the performance of agriculture are inextricably linked to quotidian farm life.

Political ecology has become a diverse term, applied with equal fervor in the analysis of capital and the socioecological consequences of US American lawn care (Robbins 2007), Costa Rican pesticide regulations (Galt 2009), obesity (Guthman 2011), famine (Ross 1998; Watts 1983), or the transnational coffee trade (West 2012) - to name a few. In the context of agriculture and performance, a political ecology perspective recognizes that farmer improvisations and repertoires are also constrained within social expectations and the political economy. As a discipline, political ecology is well suited to destabilizing the seeming inevitability of environmental decision-making and illuminating, for example, the political economy that incentivizes the consumption of sugar (Mintz 1986) or the racial disparities of migrant labor on American fruit farms (Holmes 2013). While we argue that improvisation and innovation are crucial elements in the farming process, and that this perspective corrects for some of the implicit ethnocentrism in agricultural development (Escobar 1995), they do not occur in isolation. Extending the performance metaphor, this wider context is the stage on which farmers perform. Completed farm fields tell a story enmeshed in both ecological, impromptu decisions and in a wider context of local expectations, development incentives, agribusiness quotas, and commodity pricing. 
Where the notion of performance and improvisation suggest impromptu decision-making, agricultural performances also include elements of planning and staging (Batterbury 1996). In this collection, we use performance to refer to both the improvisations of farmers in the field and to the carefully constructed plans of farmers navigating a political economy.

This dialectic lies at the core of a political ecology of agricultural performance, which recognizes that improvisations occur within the constraints and opportunities of local and global socioecological life. As in Richards' description, musical metaphors are useful here. A free improvisation concert performed by a group of musicians illustrates evidence of both. The players construct their performance as a dynamic response to the sounds they heard earlier in the day, the acoustics of the room, their moods, or the inspirations they receive from each other. The process is entirely improvised from a repertoire of musical training if viewed within the context of the performance. However, other elements of the event require careful planning - set breaks are timed to coincide with drink orders, without which the venue would not be able to support experimental music; the sound equipment must be carefully arranged to ensure that musicians and audience members can hear clearly; musicians and hall managers lean on informal and formal networks to recruit friends and fans to the performance; the concert may be funded at the behest of an arts patron; and the event itself is likely to end in time for everyone involved to catch the last train or bus home.

The dialectic between planning and iterative impromptu decision-making argues against the inevitability of development programs or agricultural technologies by situating them within a wider social context. Exploring this push and pull also provides ethnographic nuance better suited to describing agricultural decisions and performances as they unfold. The improvisations of groups and individuals reveal how some farmers are learning to turn the opportunities of new markets to their own interests (Flachs 2016), as well as the agroecological consequences when local knowledge is eroded by a new private market (Stone 2007) or a new concept of environmentalist self-policing (Agrawal 2005). Similarly, attention to context can help explain why new technological innovations, ranging from hybrid seeds to keyboards to climate-smart policies, ultimately diffuse into widespread use (Rogers 2003). By analyzing agriculture as performance, political ecologists gain a new vocabulary to describe the contextual and improvisational elements of agricultural life. The constituent elements of performance, including audiences, stages, scripts, front- and back-stage personae, and repertoires, allow us to attend to two key perspectives in political ecology. First, the Marxist perspective that ecological and social relationships are based in historical and material conditions and relations, wherein capitalism extracts surplus from labor and resources (Robbins 2004; West 2012). Second, the ethnographic perspective that creativity, opportunism, frustration, lived experience, competing knowledges, and thus the variation in what people know and do shapes social, economic, political, and environmental relationships (Benson 2012; Tsing 2015).

\section{Roles, stages, and knowledge in the field}

Understanding these roles and the socioecological constraints on performances within them is a growing concern in studies of agricultural development. These performances include the "superlative sufferer" of medical development literature (Heller 2015), the "show farmer" (Flachs 2017; Stone 2014) in alternative agriculture, or the script of "insecurity" in infrastructure development projects (James 2010). For playing such roles, farmers and other development subjects receive economic rewards including access to loans, urban consumers, farm equipment, or part-time work; social rewards including a network outside of ethnic or kin relationships that provides support and resources to participating farmers; and the reward of prestige through certificates conferred for 'good' production, recognition in the media, or by gaining respect in the community because of this attention. None of these various roles can exist outside the political economy, and yet these roles, often carefully planned and cultivated, then create new opportunities and constraints for improvised performances on the farm. This dialectic between planning and improvisation presents an opportunity to consider performativity within an analysis of praxis. Theoretical critiques from gender theory (Butler 1990), practice theory (Ortner 2005), science and technology studies (STS) (Haraway 2003; Latour 2010), and postcolonial studies (Pandian 2009; Subramanian 2009) argue that performers and performances are not totally 
separate. That is, through quotidian practice, it may be inappropriate or misleading to understand farmer performances and farmer performers as distinct. Rather, they simultaneously create each other.

Theories of quotidian performance suggest that in agriculture, as in any daily activity, the separation between performer and performance becomes blurred with repeated practice and the building of skill. Judith Butler's (1990) work on performativity as well as the scholarship of subjectivity and practice theory (Bourdieu 1977; Ortner 1984, 2005) ask how performer and performance simultaneously create one another within the power dynamics that govern who performs on which stages. As Gregson and Rose (2000) argue, understanding performances as products of knowing, intentional agents totally distinct from a true self, other performers, audiences, and power is fundamentally inaccurate because all such performances are enmeshed in already-established norms and claims to authority. Rather, the presentations of self-emerge from iterative social and ecological feedback that determines what is learned and how that knowledge is used in the future.

With its focus on the idiosyncrasies of knowledge, context, and discovery, research in STS has linked the performance of knowledge to the performance of self. Viewing subjects as in a constant state of mutual composition (Latour 2010), in which one 'becomes with' the multitude of human and nonhuman actors (Haraway 2008) in the farm landscape is a means to understand performances of self as preconditions of material agricultural decisions. Each performance must adjust for new slight or major variations in the audience and stage, because the process of creating, adapting, and translating knowledge within this multispecies and transcultural milieu, does not allow knowledge to be separated from the actors who engage with it (Stengers 2005, 2010). Although Goffman lacked a vocabulary to situate performance of self within power and expertise (Ong 2010) or the iterative subversions and incomplete, frictive development benchmarks (Pandian 2011; Subramanian 2009; Tsing 2005), these performances occur at the nexus of subjectivity and daily agricultural practice.

Dramaturgical metaphors help to link these quotidian performances of knowledge and self to the larger expectations of development or modernity - essentially guiding a discussion of how one ought to live (Pandian 2009). These subjective performances are inseparable from a specific postcolonial history that demands certain kinds of progress, strategic presentations of self and knowledge, and awkward reorganizations of knowledge and identity. When new technology arrives, increasing capital accumulation and commodifying labor and knowledge (Kloppenburg 2004), it also creates new authorities, experts, and subjects based on changes in and claims to agricultural knowledge, a phenomenon Akhil Gupta (1998) and A.R. Vasavi (1999) call hybridity. Yet these new elements are always reimagined by new audiences, belying a monolithic or inevitable global capitalism (Appadurai 1996; Tsing 2005) in favor of a modernity that has been "resisted, reinvented, and reconfigured in different social and historical locations" (Gupta 1998: 9).

Thus, to farm well is not merely to produce for one's household and to safeguard the future of the land (Wilken 1987) but to prove one's modernity, to show off for the community, to use new technologies, and to embrace the goals of states, agribusiness, NGOs, or patriarchs (Agrawal 2005; Pandian 2009, 2011). These new obligations and responsibilities engender new performances just as much as new technologies or policies. Indeed, striving to perform modernity or cosmopolitanism was seen to be a crucial factor in the adoption of hybrid maize (Ryan and Gross 1943), Green Revolution varieties of wheat and rice (Gupta 1998; Vasavi 1999), or tractors (Fitzgerald 2003), a move based as much in performative identity as in technological efficiency or active instruction (Stone 2016). States and agribusiness help to encourage such roles, as these generate capital and legible citizens or farms (Scott 1998). In some ways, this process can be subtle: export quotas, subsidies, sales representatives, or advertising pushes can encourage farmers or other petty commodity producers to adopt the language of agricultural capital. In other circumstances, institutions reshape landscapes in the service of a definitive political statement: defensive terraces in Peru (Langlie and Arkush 2016) and extensive territorial farming in the US Southwest secured military positions (Stone and Downum 1999) while plantations of sugar, tea, rubber, or cotton seek to civilize the land by bringing legible order and control to otherwise dangerous landscapes (Besky 2014; Dove 2011; Valenčius 2002).

Farmers must perform well in the field to fulfill duties expected of kin or neighboring households, but agricultural development expands this audience. In a development context driven by the moral question of being a good, responsible farmer, the audience extends to those gatekeepers of agrarian success: neighbors, 
relatives, and didactic intermediaries in agriculture from state, private, and non-governmental sectors (Stone 2016). The audience for agricultural performances may include neither farmers nor local people, but a general public who passes by roadside farms to witnesses agriculture as a broader symbol of progress, control, or power (Maat 2018). Thinking beyond the human, agricultural audiences include the soils, plants, animals, waterways, or deities enmeshed in relationships and obligations related to farmwork. Usefully, the theoretical lens of performance calls attention to the interactions between audience and actors - in this case, the ways in which farmers, audiences, and performances continually create each other.

Performance illuminates how individuals and communities strategically present themselves, how they improvise in response to natural and social phenomena, how they respond to different audiences, and how scripts, stages, spectacles, and roles emerge out of the daily practice of knowledge and self. To explore how agriculture might be theorized as a performance in a variety of agricultural development contexts, Flachs and Münster convened a workshop in 2017 at Heidelberg University with support from the Volkswagen Foundation and the Karl Jaspers Centre for Transcultural Studies. Because of the diversity of intervention programs and the innovative ways in which stakeholders throughout supply chains interact and exert their agency, the relationship between subjective transformation and particular socioeconomic reward structures in development programs remains under-theorized. By exploring the ways in which farmers respond to incentives and constraints within these programs as well as how farmers' own agendas and values shape development projects, this Special Section connects the complicated forces shaping farmer identity to direct environmental management. In doing so, it aims to describe a political ecology of performance in smallholding agriculture, focusing attention on the ways in which environmental management is socially mediated on the farm.

In this collection of articles, authors explore the nature of performance through charismatic individuals, agricultural intermediation, improvisation, and spectacle. By probing the roles or scripts adopted by communities and individuals, we analyze how farmers improvise in the field, cultivate identities, and promote agricultural development on their own terms. Articles concerned with performances of farmer identity discuss roles, scripts, and stages constructed in certified organic agriculture, the system of rice intensification (SRI), agrochemical marketing, Fairtrade, and other agricultural models that present alternatives to conventional or green revolution farming (Flachs 2018; Maat 2018; Münster 2018; Sen 2018). Other articles consider performance and agriculture more generally, commenting on the nature of improvisation, the construction of spectacle, and the power of charisma (Glover 2018; Richards 2018; Stone 2018).

The authors in this collection engage with farmer performances and agricultural improvisations in India, Cambodia, West Africa, and the United States to describe the contingency of development audiences, performers, institutions, roles, and scripts that emerge through the daily practice of farm work. These articles update, adapt, challenge, and expand the notion of agriculture as performance by adding analytics that engage with gender and power on the farm, as well as the ways in which performers and performances articulate with the global political economy. As scholars have observed, agricultural analyses of daily life have glossed over local social and ecological variation or inter-community disputes (Agrawal and Sivaramakrishnan 2000; Pandian 2009) missing an opportunity to engage with the myriad course-corrections and frictions of global development in studies of agrarian life (Cullather 2013; Sivaramakrishnan and Gupta 2011; Tsing 2005). The lens of performance is a tool to challenge the narrative that development or agrarian transition have been smooth and inevitable, or that they are the product of rational economic choices. Performance calls attention to the aspirations, frustrations, and negotiations of farmers, development intermediaries, and states. These articles contribute both empirical case studies in these performances and a broad theoretical revisiting of agricultural performance in the contemporary political economy.

\section{References}

Agrawal, A. 2005. Environmentality: technologies of government and the making of subjects. Durham: Duke University Press.

Agrawal, A. and K. Sivaramakrishnan (eds.). 2000. Agrarian environments: resources, representations, and rule in India. Durham: Duke University Press. 
Alcorn, J.B. and V.M. Toledo. 1998. Resilient resource management in Mexico's forest ecosystems: the contribution of property rights. In F. Berkes, C. Folke and J. Colding (eds.). Linking social and ecological systems: management practices and social mechanisms for building resilience. Cambridge: Cambridge University Press. Pp. 216-249.

Appadurai, A. 1996. Modernity at large: cultural dimensions of globalization. Minneapolis: University of Minnesota Press.

Batterbury, S.P.J. 1996. Planners or performers? Reflections on indigenous dryland farming in northern Burkina Faso. Agriculture and Human Values 13: 12-22.

Batterbury, S.P.J. 2017. The "context" for smallholder farming is a political ecology of agrarian change. N8 Agrifood conference, 12/7/2017, Durham University.

Benson, P. 2012. Tobacco capitalism: growers, migrant workers, and the changing face of a global industry. Princeton: Princeton University Press.

Besky, S. 2014. The Darjeeling distinction. Berkeley: University of California Press.

Bourdieu, P. 1977. Outline of a theory of practice. Cambridge: Cambridge University Press.

Brookfield, H.C. 2001. Exploring agrodiversity. New York: Columbia University Press.

Butler, J. 1990. Gender trouble: feminism and the subversion of identity. London: Routledge.

Crane, T.A., C. Roncoli and G. Hoogenboom. 2011. Adaptation to climate change and climate variability: the importance of understanding agriculture as performance. NJAS - Wageningen Journal of Life Sciences 57(3-4): 179-185.

Cullather, N. 2013. The hungry world: America's cold war battle against poverty in Asia. Reprint edition. Cambridge: Harvard University Press.

Dove, M.R. 2011. The banana tree at the gate: a history of marginal peoples and global markets in Borneo. New Haven: Yale University Press.

Escobar, A. 1995. Encountering development: the making and unmaking of the third world. Princeton: Princeton University Press.

Fitzgerald, D. 2003. Every farm a factory: the industrial ideal in American agriculture. New Haven: Yale University Press.

Flachs, A. 2016. Redefining success: the political ecology of genetically modified and organic cotton as solutions to agrarian crisis. Journal of Political Ecology 23(1): 49-70.

Flachs, A. 2017. "Show farmers": transformation and performance in Telangana, India. Culture, Agriculture, Food and Environment 39(1): 25-34.

Flachs, A. 2018. Development roles: contingency and performance in alternative agriculture in Telangana, India. Journal of Political Ecology 25: 716-731.

Galt, R.E. 2009. 'It just goes to kill Ticos': national market regulation and the political ecology of farmers' pesticide use in Costa Rica. Journal of Political Ecology 16(1): 1-33.

Glover, D. 2018. Farming as a performance: a conceptual and methodological contribution to the ecology of practices. Journal of Political Ecology 25: 686-702.

Goffman, E. 1956. The nature of deference and demeanor. American Anthropologist 58(3): 473-502.

Goffman, E. 1959. The presentation of self in everyday life. New York: Anchor.

Gregson, N. and G. Rose. 2000. Taking Butler elsewhere: performativities, spatialities and subjectivities. Environment and Planning D: Society and Space 18(4): 433-452.

Gupta, A. 1998. Postcolonial developments: agriculture in the making of modern India. Durham: Duke University Press.

Guthman, J. 2011. Weighing in. Berkeley: University of California Press.

Haraway, D. 2003. The companion species manifesto: dogs, people, and significant otherness. Chicago: Prickly Paradigm Press.

Haraway, D. 2008. When species meet. Minneapolis: University of Minnesota Press. 
Heller, A. 2015. Interrogating the superlative sufferer: experiencing obstetric fistula and treatment seeking in Niger. Doctoral Dissertation. St. Louis: Washington University in St. Louis.

Holmes, S. 2013. Fresh fruit, broken bodies: migrant farmworkers in the United States. Berkeley: University of California Press.

James, E.C. 2010. Democratic insecurities: violence, trauma, and intervention in Haiti. Berkeley: University of California Press.

Kloppenburg, J. 2004. First the Seed: the political economy of plant biotechnology 1492-2000. Madison: University of Wisconsin Press.

Kumar, R. 2015. Rethinking revolutions: soyabean, choupals, and the changing countryside in Central India. New Delhi: Oxford University Press.

Langlie, B.S. and E.N. Arkush. 2016. Managing mayhem: conflict, environment, and subsistence in the Andean late intermediate period, Puno, Peru. In A.M. VanDerwarker and G.D. Wilson (eds.). The archaeology of food and warfare. New York: Springer International Publishing. Pp. 259-289.

Latour, B. 2010. An attempt at a "Compositionist Manifesto". New Literary History 41(3): 471-490.

Leslie, P. and J.T. McCabe. 2013. Response diversity and resilience in social-ecological systems. Current Anthropology 54(2): 114-143.

Maat, H. 2018. Group compositions: how policy and technology are implemented in smallholder farming. Journal of Political Ecology 25: 703-715.

Mintz, S.W. 1986. Sweetness and power: the place of sugar in modern history. New York: Penguin Books.

Münster, D. 2018. Performing alternative agriculture: critique and recuperation in Zero Budget Natural Farming, South India. Journal of Political Ecology 25: 748-764.

Murdoch, J. and J. Clark. 1994. Sustainable knowledge. Geoforum 25(2): 115-32.

Netting, R.M. 1993. Smallholders, householders: farm families and the ecology of intensive, sustainable agriculture. Stanford: Stanford University Press.

Ong, A. 2010. Spirits of resistance and capitalist discipline: factorywomen in Malaysia. 2nd ed. Albany: State University of New York Press.

Orlove, B., C. Roncoli, M. Kabugo and A. Majugu. 2010. Indigenous climate knowledge in southern Uganda: the multiple components of a dynamic regional system. Climatic Change 100(2): 243-265.

Ortner, S. 1984. Theory in Anthropology since the Sixties. Comparative Studies in Society and History 26(1): 126-66.

Ortner, S. 2005. Subjectivity and cultural critique. Anthropological Theory 5(1): 31-52.

Pandian, A. 2009. Crooked stalks: cultivating virtue in South India. Durham: Duke University Press Books.

Pandian, A. 2011. Ripening with the Earth: on maturity and modernity in South India. In S. Dube (ed.). Modern makeovers: a handbook of modernity in South Asia. New Delhi: Oxford University Press. Pp. 157-169.

Richards, P. 1985. Indigenous agricultural revolution: ecology and food production in West Africa. London: Hutchinson.

Richards, P. 1989. Agriculture as a performance. In R. Chambers, A. Pacey and L.A. Thrupp (eds.). Farmer first: farmer innovation and agricultural research. London: Intermediate Technology Publications. Pp. 39-42.

Richards, P. 1993. Cultivation: knowledge or performance? In M. Hobart (ed.). An anthropological critique of development: the growth of ignorance. London: Routledge. Pp. 61-78.

Richards, P. 2018. Peasant farming as improvisation: what theory do we possess and how might it be used? Journal of Political Ecology 25: 647-655.

Robbins, P. 2004. Political ecology: a critical introduction. Oxford: Blackwell.

Robbins, P. 2007. Lawn people: how grasses, weeds, and chemicals make us who we are. Philadelphia: Temple University Press.

Rogers, E.M. 2003. Diffusion of innovations. 5th ed. New York: Free Press. 
Ross, E.B. 1998. The Malthus factor: poverty, politics, and population in capitalist development. New York: Zed Books.

Ryan, B. and N.C. Gross. 1943. The diffusion of hybrid seed corn in two Iowa communities. Rural Sociology 8(1): 15-24.

Schieffelin, E.L. 1998. Problematizing performance. In F. Hughes-Freeland (ed.). Ritual, performance, media. London: Routledge. Pp. 199-212.

Scott, J.C. 1998. Seeing like a state: how certain schemes to improve the human condition have failed. New Haven: Yale University Press.

Sen, D. 2018. Fempreneurs or organic tea farmers? Entrepreneurialism, resilience, and alternative agriculture in Darjeeling, India. Journal of Political Ecology 25: 732-747.

Sivaramakrishnan, K. and A. Gupta. 2011. Introduction: the state in India after liberalization. In K. Sivaramakrishnan and A. Gupta (eds.). The state in India after liberalization: interdisciplinary perspectives. London: Routledge. Pp. 1-28.

Stengers, I. 2005. Introductory Notes on an ecology of practices. Cultural Studies Review 11(1): 183-196.

Stengers, I. 2010. Cosmopolitics I. Minneapolis: University of Minnesota Press.

Stone, G.D. 2007. Agricultural deskilling and the spread of genetically modified cotton in India. Current Anthropology 48(1): 67-103.

Stone, G.D. 2014. Theme Park farming in Japan. Entry, G.D. Stone (ed.) https://fieldquestions.com.

Stone, G.D. 2016. Towards a general theory of agricultural knowledge production: environmental, social, and didactic learning. Culture, Agriculture, Food and Environment 38(1): 5-17.

Stone, G.D. 2018. Agriculture as spectacle. Journal of Political Ecology 25: 656-685.

Stone, G.D. and C.E. Downum. 1999. Non-Boserupian ecology and agricultural risk: ethnic politics and land control in the Arid Southwest. American Anthropologist 101: 113-128.

Subramanian, A. 2009. Shorelines: space and rights in South India. Stanford: Stanford University Press.

Sumberg, J.E. and C. Okali. 1997. Farmer's experiments: creating local knowledge. Boulder: Lynne Rienner.

Tsing, A.L. 2005. Friction: an ethnography of global connection. Princeton: Princeton University Press.

Tsing, A.L. 2015. The mushroom at the end of the world: on the possibility of life in capitalist ruins. Princeton: Princeton University Press.

Turner, V. 1970. The forest of symbols: aspects of Ndembu ritual. Ithaca: Cornell University Press.

Turner, V. 1980. Social dramas and stories about them. Critical Inquiry 7(1): 141-168.

Valenčius, C.B. 2002. The health of the country: how American settlers understood themselves and their land. New York: Basic Books.

Vanclay, F. 2004. Social principles for agricultural extension to assist in the promotion of natural resource management. Australian Journal of Experimental Agriculture 44(3): 213-222.

Vanclay, F. and G. Enticott. 2011. The role and functioning of cultural scripts in farming and agriculture. Sociologia Ruralis 51(3): 256-271.

Vanclay, F. and G. Lawrence. 1994. Farmer rationality and the adoption of environmentally sound practices; a critique of the assumptions of traditional agricultural extension. European Journal of Agricultural Education and Extension 1(1): 59-90.

Vasavi, A.R. 1999. Harbingers of rain: land and life in South Asia. Oxford University Press, USA.

Watts, M.J. 1983. Silent violence: food, famine and peasantry in northern Nigeria. Berkeley: University of California Press.

West, P. 2012. From modern production to imagined primitive: the social world of coffee from Papua New Guinea. Durham: Duke University Press.

Wilken, G.C. 1987. Good farmers: traditional agricultural resource management in Mexico and Central America. Berkeley: University of California Press. 